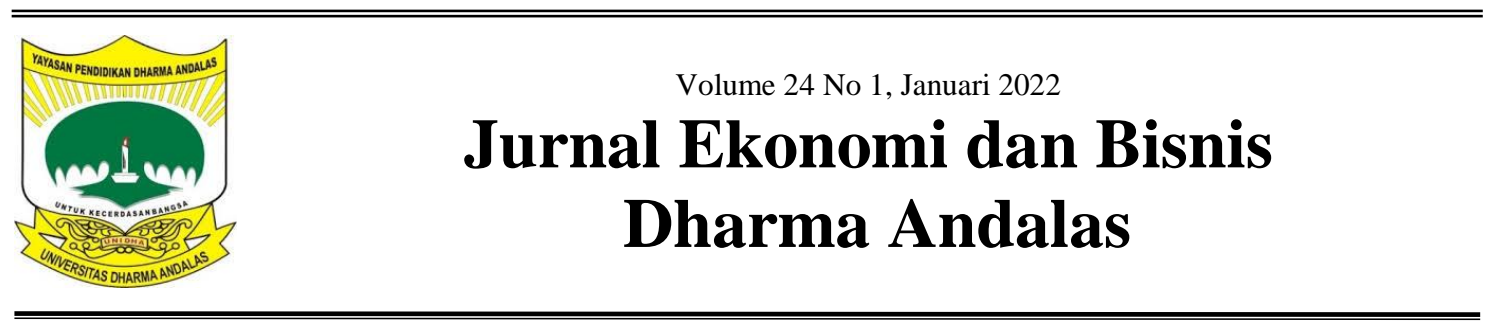

\title{
Pengaruh Intensitas Modal dan Profitabilitas terhadap Praktik Penghindaran Pajak (Tax Avoidance)
}

\author{
Murniati ${ }^{1}$, Ingra Sovita ${ }^{2}$ \\ Fakultas Ekonomi dan Bisnis Universitas Dharma Andalas ${ }^{1,2}$ \\ email:yetmurniati@gmail.com ${ }^{1}$ \\ ingra75@yahoo.com ${ }^{2}$
}

\begin{abstract}
This study aims to determine the Effect of Capital Intensity and Profitability on Tax Avoidance Practices in Food and Beverage Sector Industrial Companies listed on the Indonesia Stock Exchange (IDX) during the 2015-2019 period. Based on the sample criteria, which have been determined, the research sample obtained is 75 samples (15 companies $x$ last 5 years), sampling using purposive sampling method, Statistical analysis tool used to prove the hypothesis in this study is Multiple Linear Regression. Based on the partial hypothesis test ( $t$ test) shows that the capital intensity variable has no significant effect on tax avoidance. While profitability has a negative and significant effect on tax avoidance
\end{abstract}

Keywords: profitability capital intensity, tax avoidance practices

\begin{abstract}
ABSTRAK
Penelitian ini bertujuan untuk mengetahui Pengaruh Intensitas Modal dan Profitabilitas Terhadap Praktik Penghindaran Pajak pada Perusahaan Industri Sektor Makanan dan Minuman yang terdaftar di Bursa Efek Indonesia (BEI) selama periode 2015-2019. Berdasarkan kriteria sampel yang telah ditentukan maka sampel penelitian yang diperoleh adalah 75 sampel (15 perusahaan $\mathrm{x}$ 5 tahun terakhir), pengambilan sampel menggunakan metode purposive sampling, Alat analisis statistik yang digunakan untuk membuktikan hipotesis dalam penelitian ini adalah Regresi Linier Berganda.Berdasarkan uji hipotesis secara parsial (uji t) menunjukkan bahwa variabel intensitas modal tidak berpengaruh signifikan terhadap penghindaran pajak. Sedangkan profitabilitas berpengaruh negatif dan signifikan terhadap penghindaran pajak
\end{abstract}

Kata kunci: profitabilitas, intensitas modal, praktik penghindaran pajak

\section{LATAR BELAKANG}

Indonesia merupakan salah satu negara yang merupakan negara yang menuju fase perkembangan pembangunan nasional yang lebih baik.akan tetapi, dalam mencapai perubahan tersebut indonesia dihadapkan pada berbagai permasalahan, problementika dan kasus yang salah satunya dalam permasalahan perpajakan. Dalam peraturan perundang undangan Nomor 28 tahun 2017 pasal 1 , pajak dapat diartikan sebagai partisipasi wajib pajak terhadap negri yang terutang oleh WP orang pribadi ataupun badan yang bersifat memaksa yang berdasarkan pada perundang undangan dengan tidak mendapatkan bayaran secara terang 
terangan dengan digunakan bagi kebutuhan negara sebesarnya guna kemakmuran rakyat.Karakteristik dari perusahaan merupakan salah satu faktor perusahaan tersebut dapat melakukan penghindaraan pajak.karakteristik perusahaan yaitu capytal intenstity ratio atau rasio intensitas. Rasio intensitas dapat diartikan sebagai seberapa besar perusahaan menginvestasikan aset pada aset tetap.

Secara tradisional,penghindaran pajak juga dapat disebut sebagai kegiatan yang dilakukan oleh perusahaan yang nantinya dapat meningkatkan nilai dari perusahaan. Dalam penghindaran pajak perilaku dapat mencerminkan adanya kepentingan pribadi manajer dengan cara melakukan suatu manipulasi laba yang akan mengakibatkan adanya informasi yang tidak benar dan kegiatan tersebut tentunya akan memberikan sebuah efek kepada pemegang saham yang dimana mengakibatkan menurunnya kandungan informasi dari laporan keuangan perusaha sehingga akan berpotensi terjadinya sebuah asimetri informasi antara perusahaan dengan pemegang saham.

Perilaku dalam penghindaran pajak yang dilakukan dengan cara mengurangi pajak perusahaan namun dengan cara cara yang diperbolehkan dalam peraturan perpajakan yang ada dan sehingga nanti akan menaikkan laba perusahaan dan berdampak pada nilai perusahaan tersebut. Pada sisi lain penghindaran pajak juga diperbolehkan, akan tetapi dilihat dari sisi lain penghindaran pajak dapat mengurangi penerimaan negara. Penghindaran pajak juga dapat dipengaruhi oleh tata kelola perusahaan yang dikenal dengan Corporate Governance yaitu kegiatan penghindaran pajak yang menjadi hal yang penting dan yang harus diperhatikan oleh fiskus. Penghindaran pajak diprokiskan dengan book tax gaap (BTG),yang merupakan selisih antara laba sebelum pajak dengan penghasilan kenak pajak.

Aktivitas praktik penghindaran pajak yang digunakan sesuai dengan undang undang perpajakan maka aktivitas yang legal dan dapat diterima dan disisi lain tax avoidance tidak diinginkan pemerintah karena mengurangi pendapatan negara dan tax avoidance juga dapat menyebabkan pengurangan besar dalam pendapatan negara yang juga berdampak buruk bagi kebijakan kesejahteraan negara dan pemerintah.

Pajak juga merupakan pungutan wajib yang dibayar oleh rakyat untuk negara dan akan digunakan untuk kepentingan pemerintah dan masyarakat umum. Wajib pajak di Indonesia dapat dibagi menjadi dua,yaitu wajib pajak pribadi dan wajib pajak badan. Menurut pengusaha yang menggunakan pajak,pemerintah mempungut pajak dinilai terlalu besar sehingga menjadi beban dan mengurangi bala yang diperoleh. Maka pengusaha banyak melakukan penghindaran pajak atau yang disebut dengan tax avoidance.

Fenomena penghindaran pajak yang terdapat pada Kasus pajak di Indonesia yaitu pada PT. Asian Agri yang beroperasi dibidang pertanian dan perkebunan.Berdasarkan hasil penyelidikan Komisi Pemberantasan Korupsi (KPK) yang berkoordinasi dengan Direktorat Jendral Pajak (DJP),ditemukan penggelapan pajak Penghasilan (PPh) dan Pajak Pertambahan Nilai (PPN). Pada tahun pajak 2002 sampai dengan tahun 2005 PT.Asian Agri melakukan penyimpangan pada perusahaan hingga mencapai Rp 1,5 triliun, perusahaan mencatat kerugian transaksi ekspor Rp 232 miliar, mengecilkan hasil penjualan $\mathrm{Rp} 889$ miliar. Demikian PT. Asian Agri diduga telah melakukan penggelapan pajak senilai total Rp 2,6 triliun. Hitungan akhir 
menyebutkan bahwa penggelapan diduga berpotensi sangat merugikan keuangan negara hingga $\mathrm{Rp}$ 1,3 triliun .

Menurut atika saputri,(2018) intensitas modal diproyeksikan menggunakan rasio intensitas asset tetap.Perusahaan yang memiliki intensitas asset tetap pinggi akan menghasilkan biaya depresiasi tinggi yang dapat dikurangi atau mengurangi pajak yang harus dibayar. Semakin tinggi aset tetap,semakin tinggi biaya depresiasinya sehingga laba menjadi turun dan beban pajak menjadi turun juga. Jadi,semakin tinggi jumlah aset yang dimiliki perusahaan akan mendorong perusahaan melakukan tax avoidance.

Dan intensitas modal juga merupakan sebesar besar perusahaan yang menginvestasikan asetnya dalam bentuk aset tetap dan persediaan aset tetap perusahaan juga dapat mengalami penyusutan. Dalam undang pasal 6 nomor 36 tahun 2008 tentang penghasilan pajak , beban atas pengeluaran untuk memperoleh harta wujud dan amortisasi atas pengeluaran untuk memperoleh hak atas biaya lain yang mempunyai masa manfaat yang lebih dari satu tahun yang dapat mengurangi penghasilan kenak pajak dalam negri maupun luar negri.

Fluktuasi bisnis yang berdampak besar terhadap keuntungan anggota koperasi bila sebagian modal dibiayai oleh utang dari luar. Rasio intensitas modal yang semakin bertambah berarti efisien penggunaan aktiva tersebut dalam menghasilkan penjualan,kondisi tersebut membuat hambatan untuk masuknya anggota baru dalam koperasi simpan pinjam karena lebih banyak menggunakan asset untuk menghasilkan setiap unit penjualan.

Beban penyusutan tersebut sangat bersifat deductible expense yang akan mengurangi penghasilan kenak pajak perusahaan. Dengan tingginya perusahaan menginvestasikan dana dalam bentuk asset tetap maka semakin besar penyusutahn asset tetap tersebut maka semakin besar penyusutan dari asset tetap tersebut sehingga semakin kecil tingkat pajak dibayarkan dan sehingga penghindaran pajak yang dilakukan perusahaan semakin tinggi juga.

$\begin{array}{lrr}\text { Profitabilitas merupakan } & \text { salah } \\ \text { satu pengukuran kinerja } & \text { suatu } \\ \text { perusahaan,profitabilitas juga } & \text { dapat } \\ \text { menggambarkan kemampuan } & \text { suatu } \\ \text { perusahaan dalam menghasilkan laba } \\ \text { selama periode tertentu pada tingkat } \\ \text { penjualan,asset dan modal saham } \\ \text { tertentu.Profitabilitas }\end{array}$ menggambarkan bagaimana kinerja keuangan perusahaan dalam menghasilkan laba dari pengelolaan aktiva yang dikenal dengan Return On Asset. Laba yang meningkat profit perusahaan laba yang menyebabkan jumlah pajak yang harus dibayarkan juga semakin tinggi sehingga dapat menimbulkan kecenderungan atau kemungkinan upaya perusahaan untuk melakukan tindakan tax avoidance.

Laba perusahaan merupakan indikator yang kemampuan perusahaan untuk memenuhi kewajiban bagi para pemilik modal. Alasan terutama perusahaan beroperasi adalah menghasilkan laba yang bermanfaat bagi pemegang saham,laba perusahan yang menunjukkan prospek perusahaan dimasa depan.

Dalam rangka meminimumkan kewajiban pajak dapat dilakukan berbagai cara baik yang masih memenuhi ketentuan perpajakan (lawful) yang disebut dengan penghindaran pajak (tax avoidance) maupun yang melanggar peraturan perpajakan (unlawful) yang disebut dengan penggelepan pajak (tax avoidance). Sehingga penghindaran yang legal tidak dapat dipisahkan dengan penggelapan yang ilegal dengan alasan bahwa sebagian besar perilaku disekitar 
transaksi secara teknis adalah legal dan legalitas transaksi penghindaran pajak (tax avoidance) yang sering ditetapkan tidak sesuai dengan fakta.

Rumusan Masalah penelitian adalah; (1) Bagaimana mengetahui pengaruhProfitabilitasterhadap

penghindaran pajak; (2) Bagaimana mengetahui pengaruh intensitas modal terhadap pajak;(3)Bagaimana mengetahui pengaruh Profitabilitasdan intensitas modal terhadap penghindaran pajak.

\section{Kerangka penelitian}

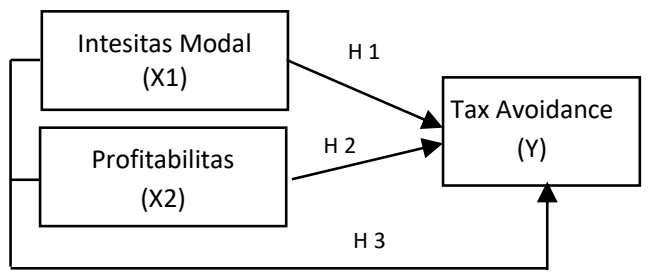

\section{Pengembangan Hipotesis}

1.Pengaruh Intensitas Modal terhadap Penghindaran Pajak

Intensitas Modal adalah aktivitas investasi dimana pada pelaksanaannya dilakukan oleh perusahaan dalam bentuk aset tetap. Dibandingkan dengan perusahaan lain, perusahaan dengan modal yang intensif memiliki peluang lebih besar untuk strategi penghindaran pajak. Berdasarkan teori keagenan dimana manejer untuk memenuhi kepentingan individu dalam mencapai kompensasi kinerja yang maksimal, manajer melakukan pengurangan beban pajak perusahaan agar mendapatkan laba yang tinggi.

Menurut C Kebjikan investasi dinilai dapat mempengaruhi tindakan penghindaran pajak (tax avoidance) yang akan dilakukan perusahaan. Apabila suatu perusahaan memutuskan untuk berinvestasi menggunakan aset, maka perusahaan dapat memanfaatkan depresiasi sebagai biaya yang dapat dikurangkan dari penghasilan atau bersifat deductible expense. Biaya penyusutan yang bersifat deductible expense nantinya akan menyebabkan laba kenak pajak perusahaan menjadi berkurang dan jumlah pajak yang harus dibayar juga akan berkurang. Berdasarkan hal tersebut, maka dirumuskan hipotesis sebagai berikut :

$\mathrm{H} 2$ : Intensitas Modal berpengaruh terhadap penghindaran pajak.

\section{Pengaruh Transfer Pricing terhadap Penghindaran Pajak Melalui Profitabilitas sebagai variabel Moderasi}

Menurut Atika Saputri, (2018) Profitabilitas merupakan salah satu pengukuran bagi kinerja suatu perusahaan.Profitabilitas pada suatu perusahaan menggambarkan kemampuan suatu perusahaan dalam menghasilkan sebuah laba selama periode tertentu pada suatu tingkat penjualan.,asset dan Modal saham tertentu.

Hasil penelitian menemukan bahwa profitabilitas berpegaruh negative terhadap penghindaran pajak. Semakin tinggi tingkat pengungkapan Profitabilitas pada perusahaan, diharapkan akan semakin rendah tingkat penghindaran pajak perusahaan. Terkait dengan hal tersebut, pengguna skema Tranfer Pricing untuk menghindari pajak merupakan suatu tindakan yang tidak beretika dan dapat merusak reputasi perusahaan dimasyarakat dan negara sehingga akan mengganggu legitimasi perusahaan pada lingkup yang lebih luas.

$\mathrm{H} 2$ :Profitabilitas memperlemah pengaruh negatif Tranfer Pricing terhadap penghindaran Pajak

\section{METODOLOGI PENELITIAN}

Penelitian ini dilakukan pada Perusahaan Manufaktur yang terdaftar di Bursa Efek Indonesia (BEI) periode 2015-2019. Data yang digunakan dalam penelitian ini adalah laporan keuangan perusahaan manufaktur yang telah 
terdaftar pada website resmi Bursa Efek Indonesia seperti www.idx.co.id.

Variabel penelitian yang digunanakan yakni Tranfer Pricing dan Intensitas Modal terhadap Praktik Penghindaran Pajak (Tax Avoidance) Dengan Profitabilitas Sebagai Variabel Moderasi.

\section{Variabel Penelitian}

Didalam penelitian ini variabel yang diteliti ada tiga variabel yaitu :

1. Variabel Dependen (Y)

Pada penelitian ini yang menjadi variabel dependen adalah :

Tax Advoidance (Y)

Pengukuran Penghindaran Pajak adalah

$$
\text { CASH ETR }=\frac{\text { Pembayaranpajak }}{\text { Labasebelumpajak }}
$$

2. Variabel Independen (X)

Pada penelitian ini yang menjadi variabel independen adalah:

a. Intensitas Modal (X1)

Intensitas modal merupakan suatu aktivitas investasi perusahaan yang berbentuk aset tetap yang biasanya diukur menggunakan rasio aset tetap dibagi dengan total aset perusahaan.

CAPINT $=\frac{\text { ASET TET AP }}{\text { TOTAL ASET }}$

b. Profitabilitas

Profitabilitas rasio adalah menggambarkan kemampuan perusahaan dalam memperoleh laba dalam memperoleh laba dalam periode tertentu.Tujuan akhir yang ingin dicapai perusahaan yang terpenting adalah memperoleh laba atau keuntungan yang maksimal.dengan memperoleh laba yang maksimal seperti yang telah ditargetkan,perusahaan dapat berbuat banyak bagi kesejahteraan pemilik,karyawan,serta meningkatkan mutu produk dan melakukan investasi baru. Return On Assets (ROA), Rasio ini dapat dihitung sebagai berikut :

$$
\begin{array}{r}
\mathrm{ROA}=\frac{\text { laba bersih setelah pajak }}{\text { total aset }} \times 100 \% \\
\text { Populasi penelitian dilakukan }
\end{array}
$$
pada Perusahaan Industri Sektor Makanan dan Minuman yang terdaftar di Bursa Efek Indonesia (BEI) selama periode 2015-2019, dan diperoleh populasi sebanyak 134 perusahaan manufaktur yang terdaftar di BEI.

Sampel

Menurut Sugiyino (2011) Sampel merupakanbagian dari jumlah dan karakteristik yang dimiliki oleh populasi tersebut. Dalam pengambilan sampel yang akan diteliti, peneliti menggunakan teknik pengambilan sampel purposive sampling dimana teknik pengambilan sampel dengan kriteria atau syarat tertentu.

Pertimbangan-pertimbangan

dalam menentukan sampel dari Perusahaan Manufaktur Sektor Makanan dan Minuman yang terdaftar di Bursa Efek Indonesia Tahun 2015 - 2019dengan kriteria-kriteria sebagai berikut :

a. Perusahaan yang dijadikan sampel adalah perusahaan Perusahaan Manufaktur Sektor Makanan dan Minuman yang terdaftar di Bursa Efek Indonesia Tahun 2015 - 2019.

b. Perusahaan yang dijadikan sampel adalah Perusahaan Manufaktur Sektor Makanan dan Minuman yang terdaftar di Bursa Efek Indonesia Tahun 2015 2019.

c. Perusahaan yang menyediakan laporan keuangan tahunan dari tahun 2015 2019.

d. Perusahaan yang memiliki nilai ROA positif dari tahun 2015-2019

\section{Tabel 1}

Penarikan Sampel Penelitian

\begin{tabular}{llc}
\hline No & \multicolumn{1}{c}{ Pernyataan } & Jumlah \\
\hline 1. & $\begin{array}{l}\text { Perusahaan industri sektor makanan dan } \\
\text { minuman yang terdaftar di Bursa Efek } \\
\text { Indonesia tahun 2015-2019 }\end{array}$ & 26 \\
\end{tabular}




\begin{tabular}{llc}
\hline No & Pernyataan & Jumlah \\
\hline 2. & $\begin{array}{l}\text { Perusahaan industri sektor makanan dan } \\
\text { minuman yang tidak mempublikasikan } \\
\text { laporan keuangan tahun 2015-2019 }\end{array}$ & $(6)$ \\
\hline & Jumlah Sampel & 20 \\
\hline
\end{tabular}

Sumber : www.idx.co.id

Sumber Data

Penelitian ini menggunakan data sekunder.Data sekunder adalah sumber data penelitian yang diperoleh secara tidak langsung, melalui media perantara. Data sekunder tersebut berupa laporan tahunan perusahaan industri sektor makanan dan minumanselama periode 2015-2019 yang diperoleh dari situs BEI yaitu www.idx.co.id, website masing-masing perusahaan dan lain-lain.

Teknik Pengumpulan Data

Metode pengumpulan data yang digunakan dalam penelitian ini adalah metode dokumentasi dan kepustakaan.

1. Metode dokumentasi adalah metode yang digunakan untuk mencatat datadata yang ada di laporan keuangan dan data-data yang tercatat pada perusahaan yang mengalami kerugian pada Bursa Efek Indonesia.

2. Studi kepustakaan adalah studi yang digunakan untuk memperoleh teoriteori yang berhubungan dengan penelitian ini, dimana teori ini diambil dari jurnal, dan penelitian terdahulu.

Metode Analisis Data

Metode analisi data dalam penelitian ini menggunakan statistik deskriptif dan analisis regresi berganda. Analisis data yang diperoleh dalam penelitian ini akan menggunakan teknologi komputer yaitu program SPSS versi 23.

Berdasarkan penelitian Sugiyono (2017) Statistika deskriptif adalah statiska yang digunakan untuk menganalisis data dengan cara mendeskripsikan atau menggambarkan data yang telah terkumpul sebagaimana adanya tanpa bermaksud membuat kesimpulan yang beraku untuk umum atau generealisasi. Penelitian menggunakan statistic deskriptif yang terdiri dari rata-rata (mean), standar deviasi, minimum dan maksimum. Umumnya statistik deskriptif digunakan oleh peneliti untuk memberikan gambaran mengenai karakteristik variabel penelitian yang sama.

Penelitian ini mengujakan ujiasumsi klasik berupa uji normalitas uji multikolinearitas, uji heteroskedastisitas, dan uji autokorelasi. Setelah memenuhi Uji asumsi maka dilakukan analisis regresi linear berganda

Berdasarkan penelitian Sugiyono (2017) Analisis regresi linear berganda merupakan regresi yang memiliki satu variable dependen dan dua atau lebih variable independen.

Terdapat dua persmaan analisis regresi linear berganda dalam penelitian ini yaitu:

$$
\mathrm{Y}=\alpha+\beta_{1} \mathrm{X}_{1}+\beta_{2} \mathrm{X}_{2}+e
$$

Keterangan :

Y : Variabel Dependen

$\alpha \quad$ : Harga Konstanta

$\beta_{1} \beta_{2}$ : Koefisien Regresi Pertama

$X_{1}$ : Variabel Independen Pertama

$\mathrm{X}_{2} \quad$ : Variabel Independen Kedua

$e \quad$ : Error atau pengaruh luar

Berdasarkan penelitian Sugiyono (2017) Uji t (t-test) melakukan pengujian terhadap koefisien regresi secara parsial, pengujian ini dilakuakn untuk mengetahui signifikan peran secara parsial antara variable independen terhadap variabel dependen dengan mengansumsikan bahwa variabel independen lain dianggap konstan.

Uji statistik $\mathrm{t}$ disebut juga uji signifikan individual. Uji ini menunjukkan seberapa jauh pengaruh variabel independen secara parsial 
terhadap variabel dependen. Pada akhirnya akan diambil suatu kesimpulan $\mathrm{Ho}$ ditolak atau $\mathrm{Ha}$ diterima

Pada pengujian simultan akan diuji pengaruh kedua variabel independen secara bersama-sama terhadap variable dependen. Statistik uji yang digunakan pada pengujian simultan adalah uji $\mathrm{F}$ yang biasa disebut Analysis of Varian (ANOVA)

Analisis berikutnya yang dilakukan aalah analisis koefisien determinasiNilai koefisien determinasi $\left(\mathrm{R}^{2}\right)$ menunjukkan persentase pengaruh semua variable independen terhadap variable dependen baik secara parsial maupun simultan.

\section{HASIL DAN PEMBAHASAN}

Statistik Deskriptif

Deskripsi data dapat penelitian dapat dilihat dari tabel berikut

Tabel 2

Deskripsi data

Descriptive Statistics

\begin{tabular}{lcccccc}
\multicolumn{5}{c}{ Descriptive Statistics } \\
& $\mathrm{N}$ & $\begin{array}{c}\text { Minimu } \\
\mathrm{m}\end{array}$ & $\begin{array}{c}\text { Maximu } \\
\mathrm{m}\end{array}$ & Mean & $\begin{array}{c}\text { Std. } \\
\text { Deviation }\end{array}$ \\
\hline CETR & 75 & .09 & .60 & .2540 & .06342 \\
CAPIN & 75 & .02 & .78 & .3768 & .16332 \\
ROA & 75 & -9.71 & 52.67 & 9.4133 & 9.73539 \\
$\begin{array}{l}\text { Valid N } \\
\text { (listwise) }\end{array}$ & 75 & & & & & \\
\hline
\end{tabular}

Sumber : Olahan Data SPSS 2021

Berdasarkan tabel 2 menunjukkan bahwa dilihat pada penghindaran pajak, Perusahaan Manufaktur Sektor Makanan dan Minuman yang terdaftar di Bursa Efek Indonesia Tahun 2015 - 2019 memiliki nilai rata-rata sebesar 0.2540 dengan standar deviasi sebesar 0.6342 . Kemudian nilai penghindaran pajak yang paling tinggi sebesar 0.60 , sedangkan nilai penghindaran pajak yang paling rendah sebesar 0.09 .

Pada intesitas modal Perusahaan Manufaktur Sektor Makanan dan Minuman yang terdaftar di Bursa Efek
Indonesia Tahun 2015 - 2019 memiliki nilai rata-rata sebesar 0.3768 dengan standar deviasi sebesar 0.16332 . Kemudian nilai intesitas modal yang paling tinggi sebesar 0.78, sedangkan nilai intesitas modal yang paling rendah sebesar 0.02 .

Pada profitabilitas Perusahaan Manufaktur Sektor Makanan dan Minuman yang terdaftar di Bursa Efek Indonesia Tahun 2015 - 2019 memiliki nilai rata-rata sebesar 9.4133 dengan standar deviasi sebesar 9.73539. Kemudian nilai profitabilitas yang paling tinggi sebesar 52.67, sedangkan nilai profitabilitas yang paling rendah sebesar -9.71 .

Uji Normalitas

Dalam penelitian ini, hasil pengujian normalitas dapat ditunjukan oleh tabel 5:

Tabel 3

Hasil Uji Normalitas

One-SampleKolmogorov-Smirnov Test

\begin{tabular}{|c|c|c|}
\hline & & $\begin{array}{l}\text { Standardized } \\
\text { Residual }\end{array}$ \\
\hline \multirow[t]{2}{*}{$\mathrm{N}$} & & 74 \\
\hline & Mean & .0000000 \\
\hline \multirow[t]{2}{*}{ Normal Parameters ${ }^{a, b}$} & $\begin{array}{l}\text { Std. } \\
\text { Deviation }\end{array}$ & .22482162 \\
\hline & Absolute & .153 \\
\hline MIOst Extreme & Positive & .085 \\
\hline DHETERES & Negative & -.153 \\
\hline Kolmogorov-Smirnov Z & & 1.315 \\
\hline Asymp. Sig. (2-tailed) & & .063 \\
\hline
\end{tabular}

Sumber : Olahan Data SPSS 2021

Berdasarkan tabel 3 dapat dilihat bahwa nilai asympsign dari masingmasing variabel memiliki nilai 0.063 > 0.05 . Hal ini menunjukkan bahwa data terdistribusi normal dan bisa dilanjutkan pada uji selanjutnya.

Uji Multikolinieritas

Multikolinearitas menunjukkan adanya lebih dari satu hubungan linier yang sempurna. Hal tersebut seperti yang telah dikemukakan oleh Santoso (2012) bahwa tujuan uji multikolinearitas adalah untuk menguji apakah pada model regresi ditemukan adanya korelasi antar variabel independen. Untuk mengetahui ada 
tidaknya multikolinieritas dapat dilihat dari nilai tolerance dan VIF (Variance Inflation Faktor). Dalam penelitian ini hasil uji multikolinearitas adalah sebagai berikut:

Tabel 4

\section{Uji Multikolinieritas} Coefficients

\begin{tabular}{llll}
\hline \multirow{2}{*}{ Model } & \multicolumn{3}{l}{ Collinearity Statistics } \\
\cline { 3 - 4 } & \multicolumn{2}{l}{ Tolerance } & VIF \\
\hline & (Constant) & .945 & 1.059 \\
1 & LN_CAPIN & .945 & 1.059 \\
\hline
\end{tabular}

a. Dependent Variable: LN_CETR

Sumber : Olahan Data SPSS 2021

Berdasarkan tabel 4 dapat dilihat bahwa nilai tolerance dari masingmasing variabel memiliki nilai $>0.10$ dan nilai VIF dari masing-masing variabel memiliki nilai $<10$. Hal ini menunjukkan bahwa data Tidak terjadi gejala multikolinearitas dan bisa dilanjutkan pada uji selanjutnya.

Dalam penelitian ini hasil pengujian heterokedaktisitas ditunjukkan oleh gambar berikut:

Scatterplot

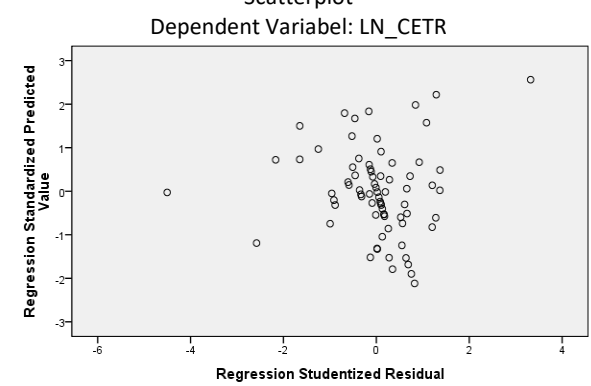

Sumber : Olahan Data SPSS 2021

Gambar 2 Uji Heteroskedastisitas

Berdasarkan gambar diatas dapat dilihat bahwa butiran-butiran pada gambar berada diatas dan dibawah nol. Hal ini menunjukkan bahwa data tidak terjadi heterokedatisitas dan bisa dilanjutkan pada uji selanjutnya.

Uji Autokorelasi

Dalam penelitian ini uji autokorelasi adalah sebagai berikut:
Tabel 5

Uji Autokorelasi

\begin{tabular}{cccccc}
\hline Model & $\mathbf{R}$ & $\begin{array}{c}\mathbf{R} \\
\text { Square }\end{array}$ & $\begin{array}{c}\text { Adjusted R } \\
\text { Square }\end{array}$ & $\begin{array}{c}\text { Std. Error of } \\
\text { the Estimate }\end{array}$ & $\begin{array}{c}\text { Durbin- } \\
\text { Watson }\end{array}$ \\
\hline 1 & $.371^{\text {a }}$ & .174 & .147 & 0.22797 & 1.470 \\
\hline a. Predictors: (Constant), LN_ROA, LN_CAPIN & \\
b. Dependent Variable: LN_CETR & & \\
Sumber : ONahan Data SPSS 2021
\end{tabular}

Sumber : Olahan Data SPSS 2021

Berdasarkan tabel 5 dapat dilihat bahwa nilai Durbin Watsondari masingmasing variabel memiliki nilai -2 sampai 2 yaitu nilai Durbin Watson(1.470). Hal ini menunjukkan bahwa data Tidak terjadi gejala autokorelasi dan bisa dilanjutkan pada uji selanjutnya.

\section{Analisis Regresi Berganda}

Analisis ini digunakan untuk mengukur kekuatan dua variabel atau lebih dan juga menunjukan arah hubungan antara variabel dependen dengan variabel independen. Dalam penelitian ini analisis regresi linear berganda adalah sebagai berikut:

\section{Tabel 5}

Analisis Regresi Berganda

\begin{tabular}{|c|c|c|c|c|c|c|}
\hline & \multirow{2}{*}{ Model } & \multicolumn{2}{|c|}{$\begin{array}{l}\text { Unstandarized } \\
\text { Coefficients }\end{array}$} & \multirow{2}{*}{$\frac{\begin{array}{l}\text { Standardized } \\
\text { Coefficients }\end{array}}{\text { Beta }}$} & \multirow{2}{*}{$\mathbf{t}$} & \multirow{2}{*}{ Sig. } \\
\hline & & B & $\begin{array}{l}\text { Std. } \\
\text { Error }\end{array}$ & & & \\
\hline \multirow[t]{3}{*}{1} & (Constant) & -1.248 & .071 & & -17.579 & .000 \\
\hline & LN_CAPIN & .012 & .044 & .033 & .282 & .779 \\
\hline & LN_ROA & -.068 & .030 & -.262 & -2.225 & .029 \\
\hline
\end{tabular}

Sumber : Olahan Data SPSS 2021

Berdasarkan tabel 5 dapat diketahui persamaan regresi yang terbentuk adalah: $\mathrm{Y}=\alpha+\beta 1 \mathrm{X} 1+\beta 2 \mathrm{X} 2+\mathrm{e}$

$\mathrm{Y}=-1.248+0.012 \mathrm{X} 1-0.068 \mathrm{X} 2+\mathrm{e}$

Dari persamaan tersebut dapat dijelaskan bahwa:

1. Dari persamaan regresi berganda diatas terlihat bahwa nilai konstanta sebesar 1.248, hal ini menunjukan bahwa tanpa adapun variabel bebas yaitu intensitas modal dan profitabilitas terhadap 
penghindaran pajak adalah negatif sebesar 1.248.

2. Nilai koefisien intensitas modal (X1) yakni 0.012.Hal ini menunjukan bahwa apabila intensitas modal meningkat sebesar satu-satuan maka penghindaran pajak (Y) akan meningkat sebesar 0.012 dengan asumsi variabel profitabilitas tetap.

3. Nilai koefisien profitabilitas (X2) yakni -0.068.Hal ini menunjukan bahwa apabila profitabilitas meningkat sebesar satu-satuan maka penghindaran pajak(Y) akan menurun sebesar 0.068 dengan asumsi variabel profitabilitas tetap.

Uji Kelayakan Model (Uji $F$ )

$$
\text { Menurut Ghozali }
$$

menyatakan bahwa ketepatan fungsi regresi sampel dalam menaksirkan nilai aktual dapat diukur dengan goodness of fit. Uji statistik $F$ ini digunakan untuk menguji apakah model persamaan yang terbentuk masuk dalam kriteria cocok (fit) atau tidak, apakah variabel independen (bebas) yang digunakan dalam model mampu menjelaskan perubahan nilai variabel dependen (terikat) atau tidak. Dalam penelitian ini, uji f adalah sebagai berikut :

\begin{tabular}{|c|c|c|c|c|c|c|}
\hline \multicolumn{7}{|c|}{$\begin{array}{c}\text { Tabel } 6 \\
\text { Ujji f } \\
\text { ANOVA }^{\mathrm{a}}\end{array}$} \\
\hline \multicolumn{2}{|c|}{ Model } & $\begin{array}{l}\text { Sum of } \\
\text { Squares }\end{array}$ & Df & $\begin{array}{l}\text { Mean } \\
\text { Square }\end{array}$ & $\mathbf{F}$ & Sig. \\
\hline \multirow[t]{3}{*}{1} & Regression & .293 & 2 & .146 & 3.819 & $.046^{\mathrm{a}}$ \\
\hline & Residual & 3.690 & 71 & .052 & & \\
\hline & Total & 3.983 & 73 & & & \\
\hline
\end{tabular}

a. Predictors: (Constant), LN_ROA, LN_CAPIN

b. Dependent Variable: LN_CETR

Sumber : Olahan Data SPSS 2021

Berdasarkan tabel 6 dapat diketahui uji hipotesis (f) adalah sebagai berikut :Berdasarkan uji hipotesis secara simultan (uji f) menunjukkan bahwa variabel pengaruhnya rasio pasar, likuiditas, solvabilitas dan profitabilitas berpengaruh dan signifikan terhadap harga saham. Hal ini dikarenakannilai signifikansi $(0.000)<0.05$. maka hipotesis ketiga diterima.

Uji Parsial (Uji t)

Pengujian ini bertujuan untuk mengetahui apakah masing-masing variabel independen yang dimasukan dalam model regresi linier berganda mempengaruhi variabel dependen secara parsial. Dalam penelitian ini, uji t adalah sebagai berikut:

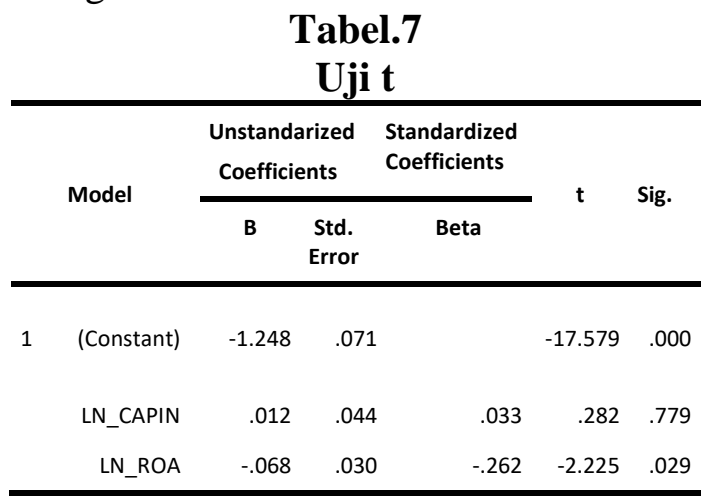

a. Predictors: (Constant), LN_ROA, LN_CAPIN

b. Dependent Variable: LN_CETR

Sumber : Olahan Data SPSS 2021

Berdasarkan tabel 7 dapat diketahui hasil uji hipotesis (t) adalah sebagai berikut:

1. Berdasarkan uji hipotesis secara parsial (uji t) menunjukkan bahwa variabel intensitas modal tidak berpengaruh signifikan terhadap penghindaran pajak. Hal ini dikarenakan nilai signifikansi (0.779) > 0.05. Maka hipotesis pertama ditolak.

2. Berdasarkan uji hipotesis secara parsial (uji t) menunjukkan bahwa variabel profitabilitas berpengaruh negatif dan signifikan terhadap penghindaran pajak. Hal ini dikarenakan nilai signifikansi $(0.029)<0.05$. Maka hipotesis kedua diterima.

Koefisien Determinasi $\left(R^{2}\right)$

Pengujian koefisien determinasi $\left(R^{2}\right)$ digunakan untuk mengukur proporsi atau presentase variabel independen yang diteliti terhadap variasi naik turunnya variabel dependen. Secara umum koefisien determinasi untuk data silang (cross section) relatif rendah karena 
adanya variasi yang besar antara masingmasing pengamatan, sedangkan untuk data runtut waktu (time series) biasanya mempunyai nilai koefisien determinasi yang tinggi (Sari, 2010).Dalam penelitian ini uji koefisien determinasi adalah sebagai berikut :

Tabel 8

Uji Koefisien Determinasi Model Summaryb

\begin{tabular}{|c|c|c|c|c|}
\hline Model & $\mathbf{R}$ & R Square & $\begin{array}{l}\text { Adjusted R } \\
\text { Square }\end{array}$ & $\begin{array}{c}\text { Std. Error of the } \\
\text { Estimate }\end{array}$ \\
\hline 1 & $.371^{\mathrm{a}}$ & .174 & .147 & 0.22797 \\
\hline \multicolumn{5}{|c|}{ a. Predictors: (Constant), LN_ROA, LN_CAPIN } \\
\hline Sumber & Olal & han Data & PSS 2021 & \\
\hline
\end{tabular}

Dari tabel diatas menunjukkan besar pengaruhnya intensitas modal dan profitabilitas terhadap penghindaran pajak adalah sebesar $14.7 \%$ sedangkan sisanya $55.3 \%$ dipengaruhi oleh faktor lainnya.

\section{Pembahasan}

Pengaruh Intensitas Modal Terhadap Penghindaran Pajak

Berdasarkan uji hipotesis secara parsial (uji t) menunjukkan bahwa variabel intensitas modal tidak berpengaruh signifikan terhadap penghindaran pajak. Hal ini dikarenakan nilai signifikansi $(0.779)>0.05$. Maka hipotesis pertama ditolak. hal ini berarti tinggi rendahnya intensitas modal pada Perusahaan Manufaktur Sektor Makanan dan Minuman yang terdaftar di Bursa Efek Indonesia Tahun 2015 - 2019, maka tidak akan berdampak pada penghindaran Pajak. Besarnya kepemilikan aset tetap tidak memberikan pengaruh yang cukup besar dalam hal mengurangi pembayaran pajak oleh perusahaan. Intensitas modal yang tinggi dalam suatu perusahaan tidak semata-mata untuk menghindari pajak melainkan dilakukan oleh perusahaan tersebut dengan tujuan menjalankan operasi perusahaan.s

\section{Pengaruh Profitabilitas Terhadap Penghindaran Pajak}

Berdasarkan uji hipotesis secara parsial (uji t) menunjukkan bahwa variabel profitabilitas berpengaruh negatif dan signifikan terhadap penghindaran pajak. Hal ini dikarenakan nilai signifikansi $(0.029)<0.05$. Maka hipotesis kedua diterima. hal ini berarti semakin tinggi profitabilitas pada Perusahaan Manufaktur Sektor Makanan dan Minuman yang terdaftar di Bursa Efek Indonesia Tahun 2015 - 2019, maka akan berdampak pada penghindaran Pajak. Menurut Atika Saputri, (2018) Profitabilitas merupakan salah satu pengukuran bagi kinerja suatu perusahaan.Profitabilitas pada suatu perusahaan menggambarkan kemampuan suatu perusahaan dalam menghasilkan sebuah laba selama periode tertentu pada suatu tingkat penjualan.,asset dan Modal saham tertentu. Hasil penelitian menemukan bahwa profitabilitas berpegaruh negative terhadap penghindaran pajak. Semakin tinggi tingkat pengungkapan Profitabilitas pada perusahaan, diharapkan akan semakin rendah tingkat penghindaran pajak perusahaan.

\section{SIMPULAN}

Berdasarkan hasil penelitian, analisis data dan pembahasan, maka diambil simpulan:

1. Berdasarkan uji hipotesis secara parsial (uji t) menunjukkan bahwa variabel intensitas modal tidak berpengaruh signifikan terhadap penghindaran pajak. Hal ini dikarenakan nilai signifikansi (0.779) > 0.05. Maka hipotesis pertama ditolak. hal ini berarti tinggi rendahnya intensitas modal pada Perusahaan Manufaktur Sektor Makanan dan Minuman yang terdaftar di Bursa Efek Indonesia Tahun 2015 - 2019, maka tidak akan berdampak pada penghindaran Pajak. 
2. Berdasarkan uji hipotesis secara parsial (uji t) menunjukkan bahwa variabel profitabilitas berpengaruh negatif dan signifikan terhadap penghindaran pajak. Hal ini dikarenakan nilai signifikansi $(0.029)<0.05$. Maka hipotesis kedua diterima. hal ini berarti semakin tinggi profitabilitas pada Perusahaan Manufaktur Sektor Makanan dan Minuman yang terdaftar di Bursa Efek Indonesia Tahun 2015 2019, maka akan berdampak pada penghindaran Pajak

Berdasarkan hasil penelitian, analisis data dan pembahasan, maka peneliti menyarankan adalah sebagai berikut:

1. Penelitian selanjutnya diharapkan dapat mempertimbangkan perusahaan yang akan dijadikan populasi dan memperluas sampel penelitian selain Perusahaan Manufaktur Sektor Makanan dan Minuman yang terdaftar di Bursa Efek Indonesia Tahun 2015 2019, agar dapat memperkuat kesimpulan yang dihasilkan dalam penelitian tersebut.

2. Bagi peneliti selanjutnya diharapkan dapat menambah variabel yang akan digunakan seperti komite audit, kualitas audit, kepemilikan institusional, umur perusahaan dan sales growth, agar hasil dari penelitian tentang penghindaran pajak lebih bervariasi.

\section{DAFTAR PUSTAKA}

Anam, Budi Safatul dkk. (2016).Pengaruh Profitabilitas dan Set Kesempatan Investasi Terhadap Kebijakan Dividen Tunai pada Perusahaan Manufaktur di Indonesia. Jurnal Magister Akuntansi Pascasarjana Universitas Syiah Kuala, vol 5, no. 3

Dinah, Aida Farah \& Darsono. (2017). Pengaruh Tata Kelola
Perusahaan, Profitabilitas, Dan

Penghindaran Pajak Terhadap

Nilai Perusahaan. Diponegoro

Journal Of Accounting Volume 6, Nomor 3.

Dwiyanti, Ida Ayu Intan. (2019). Pengaruh Profitabilitas, Capital Intensity, dan Inventory Intensity pada Penghindaran Pajak. E-Jurnal Akuntansi Universitas Udayana Vol.27.3.

Evana, Putri Scania. (2013). Pengaruh Ukuran Perusahaan, Return on Asset (ROA), Leverage dan Intensitas Modal Terhadap Tarif Pajak Efektif. JOM Fekon, Vol.3 (1).

Ginting, S. (2016). Pengaruh corporate governance dan kompensasi rugi fiskal terhadap penghindaran pajak dengan ukuran perusahaan sebagai variabel moderating. Jurnal Wira Ekonomi Mikroskil, 6, 112.

Kasmir. (2012), Analisis Laporan Keuangan. Jakarta : PT. Raja Grafindo Persada.

Mardianti, Istiqomah Vivin. (2020). Pengaruh Tanggung Jawab Sosial Perusahaan, Profitabilitas, Kepemilikan Asing, Dan Intensitas Modal Terhadap Penghindaran Pajak. jurnal Ilmu dan Riset Akuntansi : Volume 9 Nomor 4.

Refa \& Asyik, Nur Fadjrih. (2017). Pengaruh Profitabilitas, Leverage Dan Corporate Governance Terhadap Tax Avoidance. Jurnal Ilmu dan Riset Akuntansi, vol 6, no 8.

S. Tri Anggoro, and A. eptiani. (2015). Analisis Pengaruh Perilaku Penghindaran Pajak Terhadap Nilai Perusahaan Dengan Transparansi Sebagai Variabel Moderating. Diponegoro 
Journal of Accounting, vol. 4, no. 4 ,

Safitri, Wetti. (2020). Pengaruh Konservatisme Akuntansi Dan Intensitas Modal Terhadap Penghindaran Pajak Dengan Dewan Komisaris Independen Sebagai Variabel Moderasi Pada Perusahaan Manufaktur Sub Sektor Industri Barang Konsumsi Yang Terdaftar Di Bursa Efek Indonesia (BEI) Periode 2014-2017. Measurement, Vol 14 No. 2.

Saputri, Friska Atika. (2018). Pengaruh Profitabilitas, Leverage, Intensitas Modal Dan Proporsi Dewan Komisaris Independen Terhadap Tax Avoidance (Studi Pada Perusahaan Jasa Subsektor Bank yang Terdaftar di Bursa Efek Indonesia Tahun 2012-2016). Jurnal Ekobis Dewantara Vol. 1 No. 6. 